Published in final edited form as:

AIDS. 2009 November ; 23(0 1): . doi:10.1097/01.aids.0000363779.65827.e0.

\title{
Hormonal Contraception and HIV Disease Progression
}

\author{
Elizabeth Stringer ${ }^{1,3}$ and Erik Antonsen ${ }^{2,3}$ \\ ${ }^{1}$ Department of Obstetrics and Gynecology, Division of International Women's Health, University \\ of Alabama at Birmingham, Birmingham \\ 2University of Illinois at Urbana-Champaign, Champaign \\ ${ }^{3}$ Centre for Infectious Disease Research in Zambia, Lusaka, Zambia
}

\begin{abstract}
The majority of the 15.4 million human immunodeficiency virus (HIV)-infected women worldwide are of child-bearing age and need access to contraception. Hormonal methods of contraception are safe, acceptable, and effective in preventing unwanted pregnancies. Many published studies have examined the impact of hormonal contraception on HIV disease acquisition and transmissibility. Far fewer have investigated the relationship between hormonal contraception and HIV disease progression. This review examines available data on this relationship from clinical, animal, and immunological studies. Several clinical studies suggest an overall effect but are not definitive, and the mechanisms behind HIV disease progression are unclear. Animal and immunological data suggest that immunomodulation by hormonal contraceptive methods may affect the immune response to HIV infection. Additional work is needed in this area to elucidate the possible relationship between hormonal methods for birth control and progression to acquired immunodeficiency syndrome in HIV-infected women.
\end{abstract}

An estimated 15.4 million women are infected with HIV worldwide [1]. Most are in their child-bearing years and need access to safe and effective contraception. Perhaps nowhere is this need so great as in Africa, where birth rates are high and maternal mortality rates can reach $\geq 1000$ maternal deaths per 100,000 live births (100 times that observed in the industrialized world) [2]. In addition, the World Health Organization and others have identified effective contraception as a critical tool in the global effort to reduce the burden of pediatric HIV infection. In 2006, as many as 1 million perinatal HIV infections were prevented through provision of effective contraception in settings where HIV infection is highly endemic [3].

\section{HORMONAL MILIEU: PREGNANCY, CONTRACEPTION, AND MENOPAUSE}

The normal female menstrual cycle is divided by ovulation into the 2 following phases: the follicular phase, in which the maturing follicle produces estradiol to promote endometrial growth, and the luteal phase, in which the developing corpus luteum secretes progesterone to "stabilize" the endometrial lining and prepare it for implantation of a fertilized egg.

Hormonal methods of contraception work primarily by blunting the estrogen- and progesterone-mediated feedback stimulation of follicle stimulating hormone and luteinizing hormone, thus inhibiting ovulation.

(C) 2008 by the Infectious Diseases Society of America. All rights reserved.

Reprints or correspondence: Dr. Elizabeth Stringer, Centre for Infectious Disease Research in Zambia, 5977 Benekale Rd., PO Box 34681, Northmead, Lusaka, Zambia (eli@uab.edu).

Potential conflicts of interest. E.S. and E.A.: no conflicts. 
Hormonal methods differ mostly by their progesterone components and include oral contraceptive pills (OCPs), injectable progestins, progesterone-containing intrauterine devices, and progesterone implants. OCPs usually contain a combination of estrogen and progesterone, with varying progesterone formulations and potency, but progesterone-only formulations (known as the "mini pill") are also available and are often prescribed to women who are breast-feeding. The most commonly prescribed injectable method is depomedroxyprogesterone acetate (DMPA), which is given by intramuscular injection every 3 months.

The use of different types of contraception differs dramatically by region. In sub-Saharan Africa, the 2 most common methods are both hormonal: oral contraceptive pills and injectable progestins. HIV infection is not a contraindication for hormonal contraception, although the clinician must be mindful of some drug interactions, particularly with certain anti-retroviral agents.

Pregnancy is characterized by increasing levels of estrogens and progesterone, which generally plateau during the third trimester. The available literature on whether pregnancy is associated with HIV disease progression is somewhat conflicting, but in aggregate, it does not suggest a substantial association [4]. Menopause is characterized by ovarian senescence and, thereby, diminished secretion of estrogen and progesterone. Hormonal replacement therapies aim to restore premenopausal levels of estrogen to avoid bone loss, vaginal dryness, hot flashes, and other symptoms of menopause. Data on the impact of menopause on HIV disease are limited; however, 1 study revealed no impact [5].

This article reviews the relevant literature to date concerning hormonal contraceptives and HIV disease progression. We include clinical trials, animal studies, and mechanistic inquiries regarding physiologic and immunologic characteristics. We also review the currently understood pathogenesis of HIV disease progression in a model and postulate potential effects that estrogens and progesterone may have on progression of HIV disease through this model. Suggestions for future topics of investigation are presented.

\section{HIV INFECTION ACQUISITION AND TRANSMISSIBILITY}

Numerous studies have investigated the impact of hormonal contraception on HIV infection acquisition [6], and the 2 largest and most well executed of them yielded conflicting results. The Mombasa cohort enrolled 1498 HIV-uninfected women and followed up with them monthly [7]. That study is particularly valuable because women were seen frequently. This made it possible to define precisely both the timing of HIV infection acquisition and the contraceptive exposure at the time of seroconversion (this can be difficult because of the frequency of method switching). In the Mombasa study, women who used DMPA (hazard ratio, 1.8; 95\% CI, 1.4-2.4) or OCPs (hazard ratio, 1.5; 95\% CI, 1.0-2.1) had a higher risk of acquisition of HIV infection, compared with women who did not use contraception. In another large, recent prospective study involving > $6000 \mathrm{HIV}$-uninfected women in Kenya and Zimbabwe, a relationship between HIV infection acquisition and hormonal contraception was not observed [8]. However, in that study, reported condom use did not correlate with the incidence of HIV infection; thus, the study's overall interpretation was difficult.

A significant amount of attention has been given to the relationship between hormonal contraception and sexually transmitted infection acquisition. Women in the Mombasa cohort who used DMPA were much more likely to acquire Chlamydia trachomatis infection (hazard ratio, 3.1; 95\% CI, 1.0-9.4) but not Neisseria gonorrhea infection, compared with women who did not use contraception [9]. In a study consisting of a US adolescent 
population of 97 women, the authors observed an increased odds of $C$. trachomatis infection (adjusted OR, 5.44; 95\% CI, 1.25-23.6) among women who used DMPA, compared with women who used nonhormonal contraception [10].

A related issue for which data exist is the relationship between hormonal contraception and HIV infection transmissibility (typically measured through the surrogate of cervicovaginal shedding of cell-free or cell-associated virus). At least 3 studies have examined the impact of hormonal contraception on cervical shedding of cell-associated virus (measured by PCR detection of viral DNA in cervicovaginal secretions). All 3 studies demonstrated a positive relationship [11-13]. In a study involving 318 patients that was conducted in Kenya, Mostad et al. [12] revealed a dose-response effect of hormonal contraception on cervical shedding of HIV DNA. Compared with women who did not use contraception, women prescribed highdose OCPs (an older formulation that contained higher doses of estrogen than are commonly used today) were 12.3 times more likely to shed virus, women prescribed low-dose OCPs were 3.8 times more likely to shed virus, and women prescribed DMPA were 2.9 times more likely to shed virus [12].

\section{HORMONAL EFFECTS ON DISEASE PROGRESSION}

Several important studies derived from simian models have influenced our current thinking about hormonal contraception and HIV disease progression. Marx et al. [14] exposed 18 macaques to progesterone-releasing pellets and 10 macaques to no progesterone (the control macaques) before vaginally inoculating both groups with simian immunodeficiency virus (SIV). Interestingly, 14 of the 18 progesterone-treated macaques acquired SIV infection, and only 1 of the 10 control macaques became infected. In addition, 3 of 18 SIV-infected macaques in the progesterone group experienced rapid progression to AIDS, compared with none of the 10 control macaques. Finally, the progesterone-treated macaques had higher viral loads during the first 3 months of infection.

Trunova et al. [15] performed a similar study in which macaques that were either DMPA treated or DMPA naive received varying inoculations of CXCR4-simian-HIV and CCR5simian-HIV. The DMPA-treated group showed a significantly higher mean peak and acute viral load 1-4 weeks after infection. In addition, the DMPA-treated macaques acquired a more genetically diverse population of simian HIV and had higher concentrations of CXCR4-tropic virus soon after infection, compared with the DMPA-naive macaques (a change in co-receptor use from CCR5 to CXCR4 correlates well with disease progression in humans [16]). The authors reported no difference in antibody production between DMPAtreated and DMPA-naive macaques; however, cellular immune response rates (using INF- $\gamma$ production as a marker) were slower among the DMPA-treated macaques than among the DMPA-naive macaques.

Abel et al. [17] revealed that a live attenuated virus vaccine for SIV in Rhesus macaques was less effective after treatment with DMPA. DMPA-treated macaques showed a significant decrease in vaccine protection and higher acute viral loads after intravaginal challenge. Similar to the findings of Trunova et al. [15], all of the DMPA-treated macaques lost previously demonstrated HIV-specific T cell INF- $\gamma$ responses 1 week after receiving DMPA.

Four major clinical studies involving humans addressed the issue of HIV disease progression in the context of hormonal contraception. In the aforementioned Mombasa cohort, women using DMPA at the time of HIV infection acquisition had a 2-fold higher viral load set point than did women who did not use contraception (increase in viral load, $0.33 \log _{10}$ copies $/ \mathrm{mL} ; P=.03$ ) [7]. Viral load set point, which is typically established $\sim 16$ 
weeks after acquisition of infection, is highly predictive of the rate of HIV disease progression [18]. In a separate article involving this same cohort, Lavreys et al. [19] revealed that women with high viral load set points were more likely to die. In addition, compared with women who were not using contraception, women using hormonal contraception (DMPA or OCPs) were >2 times more likely to have multiple viral variants detected shortly after acquisition of infection, which in turn was associated with higher viral load set points ( $4.84 \log _{10}$ copies $/ \mathrm{mL}$ vs. $4.64 \log _{10}$ copies $/ \mathrm{mL}$ ) and lower median CD4 ${ }^{+} \mathrm{T}$ cell counts ( 416 cells $/ \mu \mathrm{L}$ vs. 617 cells $/ \mu \mathrm{L} ; P=.01) 4-24$ months after acquisition of infection and with a faster rate of $\mathrm{CD} 4^{+} \mathrm{T}$ cell depletion over time [7, 19].

A randomized trial involving 599 postpartum HIV-infected women in Lusaka, Zambia, compared the copper intrauterine device with hormonal contraception (user choice of OCPs or DMPA) [20]. In that trial, women randomized to receive hormonal contraception were more likely to experience HIV disease progression than were those who used the intrauterine device (however, this outcome was an unanticipated finding and not the primary purpose of the clinical trial). Disease progression was defined separately as death and/or decrease in $\mathrm{CD}^{+} \mathrm{T}$ cell count to $<200$ cells $/ \mathrm{mm}^{3}$. Women who received hormonal contraception were more likely to die or experience a decrease in $\mathrm{CD}^{+} \mathrm{T}$ cell count (hazard ratio, $1.5 ; 95 \% \mathrm{CI}$, 1.1-2.3) than were women randomized to use the intrauterine device. This study's patient population differed from that of the Mombasa cohort; all women were enrolled during the post-partum period after having been identified through perinatal HIV infection prevention programs. Thus, all had established infections. Unfortunately, viral load data are not available from the Zambian trial.

Two other studies were published that did not observe a relationship between hormonal contraception and HIV disease progression. A subanalysis of the Women's Interagency Health Study [21], a large longitudinal cohort of HIV-infected women, compared 177 women receiving hormonal contraception with 544 women not receiving contraception. This subanalysis reported a small increase in $\mathrm{CD}^{+}{ }^{+} \mathrm{T}$ cell count in HIV-infected women using hormonal contraception (mean increase over 13 months, $27.6 \mathrm{cells} / \mu \mathrm{L}$ ) and no change in viral load over time. Limitations of this analysis are that contraceptive exposure was obtained through self-report at baseline, and the extremely common practice of switching contraceptive methods was not reported.

Richardson et al. [22] conducted a prospective cohort study composed of recently postpartum women in Kenya to characterize determinates of disease progression. An analysis of hormonal contraception and disease progression included 41 women exposed to OCPs, 43 exposed to DMPA, and 109 who were not exposed to hormonal contraception. The analysis used multivariate linear mixed effects models and Loess regression to compare the effect of these exposures on $\mathrm{CD}^{+} \mathrm{T}$ cell count and viral load over 24 months of followup. The study found no statistically significant changes in viral load or $\mathrm{CD}^{+} \mathrm{T}$ cell count that could be attributed to contraceptive exposure.

Most of the patients in the aforementioned clinical studies were not receiving antiretroviral therapy. Presumably, women receiving antiretroviral therapy who are experiencing viral suppression would not be adversely affected by factors that might accelerate disease progression in untreated women.

\section{POTENTIAL MECHANISMS}

A variety of mechanisms could explain the apparent effects of hormonal contraception on HIV infection acquisition and disease progression. Besides the more-global indicators of disease progression (i.e., viral replication and $\mathrm{CD}^{+} \mathrm{T}$ cell depletion), other markers of 
disease progression are found in the literature. These include infection with genetically heterogeneous viral populations [23]; higher expression of activation markers, such as CD38 and CD69 in both $\mathrm{CD}_{4}^{+}$and $\mathrm{CD}^{+} \mathrm{T}$ cells [24]; dominance of a Th2 cytokine profile that increases humoral response at the expense of cellular response [24]; and accumulation of regulatory $\mathrm{CD}^{+} \mathrm{T}$ cells in lymphoid tissue [25]. Senescence of $\mathrm{CD} 8^{+} \mathrm{T}$ cells has also been suggested, although this has not been sufficiently investigated [26, 27]. Estrogen and progesterone have been shown to affect many of these indicators and, therefore, may influence the immune response to HIV infection (table 1).

Figure 1 presents 1 model of pathogenesis of HIV infection. After viral entry, the initial immune response to HIV infection occurs in mucosal lymphoid tissue, where plasmacytoid dendritic cells secrete various cytokines that stimulate $\mathrm{CD} 4^{+} \mathrm{T}$ cell activation. These activated $\mathrm{CD} 4^{+} \mathrm{T}$ cells proliferate in response to HIV antigens and also become susceptible to HIV infection themselves (unactivated $\mathrm{CD}^{+} \mathrm{T}$ cells are less susceptible to infection). Activated $\mathrm{CD}^{+}{ }^{+} \mathrm{T}$ cells differentiate into 1 of 3 different phenotypes (Th1, Th2, or Th17). The Th1 immune response is characterized by more-potent clearing of HIV-infected cells (by NK cells and $\mathrm{CD} 8^{+} \mathrm{T}$ cells). A Th2 response involves increased B cell production of HIV-specific antibodies. These can reduce plasma viral load in chronically infected patients but do not systemically control the virus $[32,33]$. Recently, another subset of $\mathrm{CD}^{+} \mathrm{T}$ cells that secrete IL-17 (the "TH17 cell") was described. These CD4+ T cells are thought to be important for the control of extracellular bacterial pathogens but may also be an important determinant in HIV infection pathogenesis during early infection [34, 35]. Interestingly, 4 separate groups of authors recently demonstrated that acute infection with HIV or SIV is characterized by the loss of TH17 cells—a finding that has not been seen in African green monkeys with natural SIV infection [36-39]. The role of the different subsets of CD4 ${ }^{+} \mathrm{T}$ cells in HIV infection is complex, but it is possible that hormonal contraception modifies the cytokine responses of these cells, thereby affecting subsequent immune control of HIV infection, as well as disease progression.

Finally, accumulation of regulatory $\mathrm{CD} 4^{+} \mathrm{T}$ cells in lymphoid tissue has been associated with increased rate of disease progression [25]. This is caused in part by indolamine 2,3deoxygenase secretion from plasmacytoid dendritic cells [40] (Th17 may also play a role [35]). $\mathrm{CD} 8^{+} \mathrm{T}$ cell senescence has not been tied to indolamine 2,3-deoxygenase, but it has been observed that highly differentiated $\mathrm{CD}^{+} \mathrm{T}$ cells in a senescent state accumulate in HIV-infected individuals over time [41]. It is likely that $\mathrm{CD} 8^{+} \mathrm{T}$ cell senescence also affects HIV disease progression [26, 42]. Estrogen and progesterone receptors are found on many cells involved in the immune response, such as $\mathrm{CD} 4^{+}$and $\mathrm{CD} 8^{+} \mathrm{T}$ cells, B lymphocytes, monocytes, and neutrophils [43, 44], providing possible mechanisms for hormonal modulation of the immune response to HIV infection. Because both virus and hormones affect the immune response, susceptibility to HIV infection and HIV disease progression are difficult to separate and, indeed, may be linked. The initial condition of the immune system in women who are infected while using hormonal contraception may affect variables that have long-term consequences for disease progression, including viral load set point, acute CD8CD38, and infection with multiple viral variants. Future research will need to address how hormonal contraception affects acute versus chronic infection in the context of disease progression. In the next 2 sections of this article, we review the known effects of progesterone and estrogen on the immune system and attempt to illustrate potential areas of future research.

\section{PROGESTERONE EFFECTS}

Hughes et al. [31] demonstrated that progesterone inhibits secretion of INF- $a$ from dendritic cells. Although this effect is counteracted quickly by other sources of INF- $a$, it is critical to 
indicate that certain micropeptides are inhibited by progesterone and that INF- $a$ and indolamine 2,3-deoxygenase have specific effects on HIV infection that could be affected, to a larger extent, by progesterone and estrogen. This provides direction for future research. Progesterone also causes a shift toward a Th2 cytokine response through suppression of INF- $\gamma$, IL-12, IL-1 $\beta$, and IL-6 [15, 17, 28]. As discussed previously, a shift toward a Th2 humoral response means a shift away from a Th1 cell-mediated response, weakening the mechanism for clearance of $\mathrm{HIV}$-infected $\mathrm{CD}^{+} \mathrm{T}$ cells. Other studies have revealed that progesterone down-regulates $\mathrm{CD}^{+} \mathrm{T}$ cell cytotoxic activity through progesterone-induced blocking factor, which suppresses perforin (a cytotoxic agent) [45, 46]. Suppression of $\mathrm{CD} 8^{+} \mathrm{T}$ cell cytotoxicity could theoretically decrease the rate of removal of infected $\mathrm{CD} 4^{+} \mathrm{T}$ cells, possibly slowing disease progression; however, a decrease in $\mathrm{CD} 8^{+} \mathrm{T}$ cell cytotoxic activity could also allow uncontrolled replication of HIV-infected $\mathrm{CD}^{+} \mathrm{T}$ cells and potentially lead to further disease progression. Enomoto et al. [28] noted that progesterone decreased CD69 activation marker expression on $\mathrm{CD}^{+} \mathrm{T}$ cells, potentially affecting their ability to kill infected $\mathrm{CD} 4^{+} \mathrm{T}$ cells, but the interaction between progesterone and $\mathrm{CD} 25$ and CD38 has not been studied. The effects of progesterone on the development of cellular senescence have also not been studied.

The overall effects that progesterone have on the immune system suggest that the initial response to HIV infection could be attenuated, possibly leading to titers of circulating virus during acute infection or higher viral set points. DMPA has been shown to affect naturally occurring vaginal barriers, such as Lactobacillus species, thus increasing susceptibility to other sexually transmitted infections and, potentially, to infection with multiple HIV strains (which correlates with a higher viral set point) [7]. These effects suggest an immediately suppressed antiviral response at the time of acquisition of infection; however, discrete effects on chronic infection have not been elucidated.

\section{ESTROGEN EFFECTS}

Like progesterone, estrogens affect the immune system [47]. When estradiol concentrations are low, human $\mathrm{T}$ cells induce a Th1 response, and high concentrations induce a Th2 response [29, 30, 48]. Enomoto et al. [28] revealed that, at concentrations achieved with use of hormonal contraception, estrogens suppress a Th1 response by decreasing levels of INF$\gamma$, IL-2, and IL-6. No effect was observed on the $\mathrm{CD} 4^{+}$or $\mathrm{CD} 8^{+} \mathrm{T}$ cell activation marker $\mathrm{CD} 69$, and the effect on CD38 has not been reported. Investigators have also revealed that estrogens directly stimulate HIV-1 replication in T cells through estrogen receptor $a$ [49]. These mechanisms have the potential to increase viral load and, therefore, the numbers of infected T cells. This perhaps explains some of the clinical results revealing higher cervical viral shedding in OCP users than in DMPA users [12].

Estrogens have been shown to inhibit T cell migration to HIV-infected tissue [50]. OCP use seems to increase both the number of T cells expressing CCR5 and the density of CCR5 receptors on each T cell $[51,52]$. Because CCR5 is a required coreceptor for viral entry, this effect may be particularly important at the time of infection, when HIV-specific depletion of $\mathrm{CD}^{+} \mathrm{T}$ cells is prominent $[53,54]$. The effects of estrogens on the development of cellular senescence have not been studied.

\section{SUMMARY}

In 2 large clinical studies, hormonal contraception was associated with more-rapid $\mathrm{CD} 4^{+} \mathrm{T}$ cell depletion (a sine qua non of HIV disease progression); however, in other studies, this phenomenon was not observed. In addition, no published reports to date have revealed a substantial and sustained effect of hormonal contraception on viral load. How hormonal 
contraception might cause more-rapid depletion of $\mathrm{CD} 4^{+} \mathrm{T}$ cells without affecting plasma viral load is unclear. However, there is abundant evidence from the laboratory that the interactions between sex steroids and the immune system are complex and likely involve interactions at any number of points along the HIV lifecycle. Our review of the literature suggests that critical discoveries are yet to be made regarding hormonal contraception and the pathogenesis of HIV infection. Missing data include the effects of hormonal contraception on cellular activation (CD38 and CD25), cellular senescence (CD57, ki-67, and IL-17), and mucosal immunity (INF- $a$, indolamine 2,3-deoxygenase, and accumulation of regulatory CD4 T cells) at the concentrations achieved with hormonal contraception.

Access to safe and effective contraception is of utmost importance worldwide, especially in countries with a high prevalence of HIV infection, where every prevented undesired pregnancy could also represent a case of avoided perinatal HIV infection or maternal mortality. There is obvious need to promote the use of effective nonhormonal methods, such as the intrauterine device, which recent data suggest is very safe in HIV-infected women. However, hormonal contraceptive methods remain the most popular contraceptive methods in many parts of sub-Saharan Africa. It is therefore essential to understand their impact on HIV disease, especially in women not yet eligible to receive antiretroviral therapy.

\section{Acknowledgments}

We thank Ben Chi, Jeff Stringer, Katherine Boos, Paul Goepfert, and Mike Saag for their insightful contributions to this manuscript.

Financial support. National Institutes of Health (NIH; 1U01AI69455 to E.S.), Centers for Disease Control and Prevention (U62/CCU12354 to E.S.), International Clinical Research Scholars Program (R24TW007988 to E.A.), the AIDS International Training and Research Program (D43TW001035 to E.A.) of the Fogarty International Center-NIH, and Oak Ridge Institute for Science and Education (National Institute of Allergy and Infectious Diseases) through Department of Energy Proposal 1236-1236-06 (to E.A.).

\section{References}

1. Joint United Nations Programme on HIV/AIDS (UNAIDS), World Health Organization. Report on the global HIV/AIDS epidemic 2007. Geneva: UNAIDS; 2007.

2. Shah IH, Say L. Maternal mortality and maternity care from 1990 to 2005: uneven but important gains. Reproductive Health Matters. 2007; 15:17-27. [PubMed: 17938067]

3. Reynolds HW, Janowitz B, Homan R, Johnson L. The value of contraception to prevent perinatal HIV transmission. Sex Transm Dis. 2006; 33:350-6. [PubMed: 16505747]

4. French R, Brocklehurst $P$. The effect of pregnancy on survival in women infected with HIV: a systematic review of the literature and meta-analysis. Br J Obstet Gynaecol. 1998; 105:827-35. [PubMed: 9746374]

5. van Benthem BH, Vernazza P, Coutinho RA, Prins M. Impact of pregnancy and menopause on CD4 cell counts. J Acquir Immune Defic Syndr. 2005; 38(Suppl 1):S22. [PubMed: 15867607]

6. Wang CC, Reilly M, Kreiss JK. Risk of HIV infection in oral contraceptive pill users: a metaanalysis. J Acquir Immune Defic Syndr. 1999; 21:51-8. [PubMed: 10235514]

7. Baeten JM, Lavreys L, Sagar M, et al. Effect of contraceptive methods on natural history of HIV: studies from the Mombasa cohort. J Acquir Immune Defic Syndr. 2005; 38(Suppl 1):S18-21. [PubMed: 15867603]

8. Morrison CS, Richardson BA, Mmiro F, et al. Hormonal contraception and the risk of HIV acquisition. AIDS. 2007; 21:85-95. [PubMed: 17148972]

9. Lavreys L, Baeten JM, Martin HL Jr, et al. Hormonal contraception and risk of HIV-1 acquisition: results of a 10-year prospective study. AIDS. 2004; 18:695-7. [PubMed: 15090778]

10. Jacobson DL, Peralta L, Farmer M, Graham NM, Gavdos C, Zenilman J. Relationship of hormonal contraception and cervical ectopy as measured by computerized planimetry to chlamydial infection in adolescents. Sex Transm Dis. 2000; 27:313-9. [PubMed: 10907905] 
11. Wang CC, McClelland RS, Overbaugh J, et al. The effect of hormonal contraception on genital tract shedding of HIV-1. AIDS. 2004; 18:205-9. [PubMed: 15075537]

12. Mostad SB, Overbaugh J, DeVange DM, et al. Hormonal contraception, vitamin A deficiency, and other risk factors for shedding of HIV-1 infected cells from the cervix and vagina. Lancet. 1997; 350:922-7. [PubMed: 9314871]

13. Clemetson DB, Moss GB, Willerford DM, et al. Detection of HIV DNA in cervical and vaginal secretions: prevalence and correlates among women in Nairobi, Kenya. JAMA. 1993; 269:2860-4. [PubMed: 8497089]

14. Marx PA, Spira AI, Gettie A, et al. Progesterone implants enhance SIV vaginal transmission and early virus load. Nat Med. 1996; 2:1084-9. [PubMed: 8837605]

15. Trunova N, Tsai L, Tung S, et al. Progestin-based contraceptive suppresses cellular immune responses in SHIV-infected rhesus macaques. Virology. 2006; 352:169-77. [PubMed: 16730772]

16. Brumme ZL, Goodrich J, Mayer HB, et al. Molecular and clinical epidemiology of CXCR4-using HIV-1 in a large population of anti-retroviral-naive individuals. J Infect Dis. 2005; 192:466-74. [PubMed: 15995960]

17. Abel K, Rourke T, Lu D, Bost K, McChesney MB, Miller CJ. Abrogation of attenuated lentivirusinduced protection in Rhesus macaques by administration of depo-provera before intravaginal challenge with simian immunodeficiency virus mac239. J Infect Dis. 2004; 190:1697-705. [PubMed: 15478078]

18. Mellors JW, Rinaldo CR Jr, Gupta P, White RM, Todd JA, Kingsley LA. Prognosis in HIV-1 infection predicted by the quantity of virus in plasma. Science. 1996; 272:1167-70. [PubMed: 8638160]

19. Lavreys L, Baeten JM, Chohan V, et al. Higher set point plasma viral load and more-severe acute HIV type (HIV-1) illness predict mortality among high-risk HIV infected African women. Clin Infect Dis. 2006; 42:1333-9. [PubMed: 16586394]

20. Stringer EM, Kaseba C, Levy J, et al. A randomized trial of the intra-uterine contraceptive device vs hormonal contraception in women who are infected with the human immunodeficiency virus. Am J Obstet Gynecol. 2007; 197:144, e1-8. [PubMed: 17689627]

21. Cejtin HE, Jacobson L, Springer G, et al. Effect of hormonal contraceptive use on plasma HIV-1 RNA levels among HIV-infected women. AIDS. 2003; 17:1702-4. [PubMed: 12853757]

22. Richardson BA, Otieno PA, Mbori-Ngacha, Overbaugh J, Farquhar C, John-Stewart GC. Hormonal contraception and HIV-1 disease progression among postpartum Kenyan women. AIDS. 2007; 21:749-53. [PubMed: 17413696]

23. Sagar M, Lavreys L, Baeten JM, et al. Infection with multiple human immunodeficiency virus type 1 variants is associated with faster disease progression. J Virol. 2003; 77:12921-6. [PubMed: 14610215]

24. Langford SE, Ananworanich J, Cooper DA. Predictors of disease progression in HIV infection: a review. AIDS Res Ther. 2007; 4:11. [PubMed: 17502001]

25. Nilsson J, Boasso A, Velilla PA, et al. HIV-1-driven regulatory T-cell accumulation in lymphoid tissues is associated with disease progression in HIV/AIDS. Blood. 2006; 108:3808-17. [PubMed: 16902147]

26. Appay V, Almeida JR, Sauce D, Autran B, Papagno L. Accelerated immune senescence and HIV-1 infection. Exp Gerontol. 2007; 42:432-7. [PubMed: 17307327]

27. Papagno L, Spina CA, Marchant A, et al. Immune activation and CD8 ${ }^{+}$T-cell differentiation towards senescence in HIV-1 infection. PLoS Biol. 2004; 2:E20. [PubMed: 14966528]

28. Enomoto LM, Kloberdanz KJ, Mack DG, Elizabeth D, Weinberg A. Ex vivo effect of estrogen and progesterone compared with dexamethasone on cell-mediated immunity of HIV-infected and uninfected subjects. J Acquir Immune Defic Syndr. 2007; 45:137-43. [PubMed: 17356463]

29. Maret A, Coudert JD, Garidou L, et al. Estradiol enhances primary antigen-specific CD4 T cell responses and Th1 development in vivo: essential role of estrogen receptor alpha expression in hematopoietic cells. Eur J Immunol. 2003; 33:512-21. [PubMed: 12645950]

30. Gilmore W, Weiner LP, Correale J. Effect of estradiol on cytokine secretion by proteolipid protein-specific $\mathrm{T}$ cell clones isolated from multiple sclerosis patients and normal control subjects. J Immunol. 1997; 158:446-51. [PubMed: 8977221] 
31. Hughes GC, Thomas S, Li C, Kaja MK, Clark EA. Cutting edge: progesterone regulates IFN- $a$ production by plasmacytoid dendritic cells. J Immunol. 2008; 180:2029-33. [PubMed: 18250406]

32. Chinen J, Shearer WT. Molecular virology and immunology of HIV infection. J Allergy Clin Immunol. 2002; 110:189-98. [PubMed: 12170257]

33. Connolly NC, Riddler SA, Rinaldo CR. Proinflammatory cytokines in HIV disease-a review and rationale for new therapeutic approaches. AIDS Reviews. 2005; 7:168-80. [PubMed: 16302465]

34. Harrington LE, Mangan PR, Weaver CT. Expanding the effector CD4 T-cell repertoire: the Th17 lineage. Curr Opin Immunol. 2006; 18:349-56. [PubMed: 16616472]

35. Weaver CT, Harrington LE, Mangan PR, Gavrieli M, Murphy KM. Th17: an effector CD4 T cell lineage with regulatory $T$ cell ties. Immunity. 2006; 24:677-88. [PubMed: 16782025]

36. Cervasi, B.; Brenchley, J.; Piaiardini, M., et al. Preferential loss of Th17 CD4 T cells in the gastrointestinal tract of HIV-infected individuals but not SIV-infected sooty mangabeys [abstract 115]. Program and abstracts of the 15th Conference on Retroviruses and Opportunistic Infections; Boston, MA. 2008.

37. Checchinato, V.; Trindad, C.; Heraud, JM., et al. Preferential loss of Th17 T cells at mucosal sites predicts AIDS progression in simian immunodeficiency virus-infected macaques [abstract 116]. Program and abstracts of the 15th Conference on Retroviruses and Opportunistic Infections; Boston, MA. 2008.

38. Dandekar, S.; Rafatellu, M.; Macal, M., et al. Disruption of intestinal epithelial integrity and increased microbial translocation and systemic dissemination in HIV and SIV infections are linked to impaired IL-17-expressing mucosal T cell responses [abstract 374]. Program and abstracts of the 15th Conference on Retroviruses and Opportunistic Infections; Boston, MA. 2008.

39. Favre, D.; Lederer, S.; Kanwar, B., et al. Primary SIV infection causes rapid loss of the balance between $\mathrm{TH} 17$ and $\mathrm{T}$ regulatory cell populations in pathogenic infection of non-human primates [abstract 117LB]. Program and abstracts of the 15th Conference on Retroviruses and Opportunistic Infections; Boston, MA. 2008.

40. Boasso A, Herbeuval JP, Hardy AW, et al. HIV inhibits CD4 ${ }^{+}$T-cell proliferation by inducing indoleamine 2,3-dioxygenase in plasmacytoid dendritic cells. Blood. 2007; 109:3351-9. [PubMed: 17158233]

41. Appay V, Almeida JR, Sauce D, Autran B, Papagno L. Accelerated immune senescence and HIV-1 infection. Exp Gerontol. 2007; 42:432-7. [PubMed: 17307327]

42. Brenchley JM, Karandikar NJ, Betts MR, et al. Expression of CD57 defines replicative senescence and antigen-induced apoptotic death of $\mathrm{CD}^{+} \mathrm{T}$ cells. Blood. 2003; 101:2711-20. [PubMed: 12433688]

43. Danel L, Vincent C, Rousset F, et al. Estrogen and progesterone receptors in some human myeloma cell lines and murine hybridomas. J Steroid Biochem. 1988; 30:363-7. [PubMed: 3260311]

44. Pasanen S, Ylikomi T, Palojoki E, Syvala H, Pelto-Huikko M, Tuohimaa P. Progesterone receptor in chicken bursa of Fabricius and thymus: evidence for expression in B-lymphocytes. Mol Cell Endocrinol. 1998; 141:119-28. [PubMed: 9723893]

45. Laskarin G, Strbo N, Sotosek V, et al. Progesterone directly and indirectly affects perforin expression in cytolytic cells. Am J Reprod Immunol. 1999; 42:312-20. [PubMed: 10584987]

46. Laskarin G, Tokmadzic VS, Strbo N, et al. Progesterone induced blocking factor (PIBF) mediates progesterone induced suppression of decidual lymphocyte cytotoxicity. Am J Reprod Immunol. 2002; 48:201-9. [PubMed: 12516630]

47. Whitacre CC, Reingold SC, O’Looney PA. A gender gap in autoimmunity. Science. 1999; 283:1277-8. [PubMed: 10084932]

48. Correale J, Arias M, Gilmore W. Steroid hormone regulation of cytokine secretion by proteolipid protein-specific $\mathrm{CD}^{+}{ }^{+} \mathrm{T}$ cell clones isolated from multiple sclerosis patients and normal control subjects. J Immunol. 1998; 161:3365-74. [PubMed: 9759853]

49. Katagiri D, Hayashi H, Victoriano AF, Okamoto T, Onozaki K. Estrogen stimulates transcription of human immunodeficiency virus type 1 (HIV-1). Int Immunopharmacol. 2006; 6:170-81. [PubMed: 16399621] 
50. Zang YC, Halder JB, Hong J, Rivera VM, Zhang JZ. Regulatory effects of estriol on T cell migration and cytokine profile: inhibition of transcription factor NF- $\kappa$ B. J Neuroimmunol. 2002; 124:106-14. [PubMed: 11958828]

51. Prakash M, Kapembwa MS, Gotch F, Patterson S. Oral contraceptive use induces upregulation of the CCR5 chemokine receptor on $\mathrm{CD}^{+}{ }^{+} \mathrm{T}$ cells in the cervical epithelium of healthy women. $\mathrm{J}$ Reprod Immunol. 2002; 54:117-31. [PubMed: 11839399]

52. Reynes J, Portales P, Segondy M, et al. CD4 ${ }^{+} \mathrm{T}$ cell surface CCR5 density as a determining factor of virus load in persons infected with human immunodeficiency virus type 1. J Infect Dis. 2000; 181:927-32. [PubMed: 10720514]

53. Mehandru S, Poles MA, Tenner-Racz K, et al. Primary HIV-1 infection is associated with preferential depletion of $\mathrm{CD}^{+}{ }^{+} \mathrm{T}$ lymphocytes from effector sites in the gastrointestinal tract. $\mathrm{J}$ Exp Med. 2004; 200:761-70. [PubMed: 15365095]

54. Brenchley JM, Schacker TW, Ruff LE, et al. CD4 ${ }^{+}$T cell depletion during all stages of HIV disease occurs predominantly in the gastrointestinal tract. J Exp Med. 2004; 200:749-59. [PubMed: 15365096] 


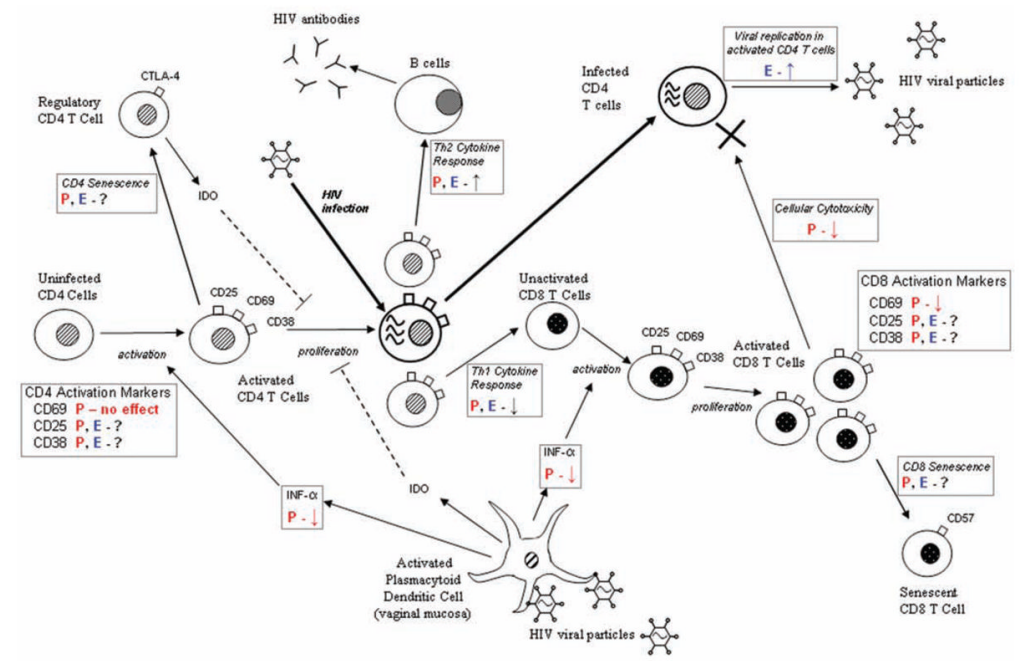

Figure 1.

Potential effects of hormonal contraception on the pathogenesis of HIV infection. Arrows pointing down indicate decreases in immune response, arrows pointing up indicate increases in immune response, and question marks indicate unknown effects. The boxed sections denote processes in which hormonal effects may be significant. E, estrogens (effects of $\mathrm{E}$ on immune responses are shown in blue); IDO, indolamine 2,3-deoxygenase; $\mathrm{P}$, progesterone (effects of $\mathrm{P}$ on immune response are shown in red). 
Table 1

Effects of estrogen and progesterone on various markers of HIV disease progression.

\begin{tabular}{|c|c|c|}
\hline \multirow[b]{2}{*}{ Marker } & \multicolumn{2}{|r|}{ Effects } \\
\hline & Estrogen & Progesterone (reference[s]) \\
\hline $\mathrm{CD} 4^{+} \mathrm{T}$ cell count ${ }^{a}$ & Conflicting results & Decrease $([7,20]) ;$ no effect $([21,22])$ \\
\hline Viral load ${ }^{a}$ & Unknown & No effect $([21,22])$ \\
\hline Viral load set point ${ }^{a}$ & Unknown & Increase ([19]) \\
\hline Cytokine profile ${ }^{a}$ & Th2 level > Th1 level & Th2 level > Th1 level \\
\hline INF- $\gamma$ level & $\begin{array}{l}\text { Decrease with high } \operatorname{dose}^{b} ; \text { increase with low } \\
\text { dose }^{c}\end{array}$ & Decrease \\
\hline IL-2 level ${ }^{b}$ & Decrease & No effect \\
\hline IL-6 level $^{b}$ & Decrease & Decrease \\
\hline IL-10 level $^{d}$ & Increase & No effect \\
\hline $\mathrm{IL}-12$ level $^{b}$ & No effect & Decrease \\
\hline 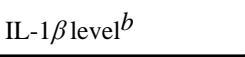 & No effect & Decrease $^{b}$ \\
\hline Chemokine receptors & Increase in CCR5 & Unknown \\
\hline Activation markers $^{a}$ & $\begin{array}{l}\text { No effect on } \mathrm{CD} 69^{b} \text {; unknown for } \mathrm{CD} 38 \text { and } \\
\text { CD25 }\end{array}$ & $\mathrm{CD} 69$ decrease on $\mathrm{CD}^{+}{ }^{+} \mathrm{T}$ cells ${ }^{b}$; unknown for $\mathrm{CD} 38$ and $\mathrm{CD} 25$ \\
\hline Viral variants $a$ & Unknown & Increased heterogeneity $([16,19])$ \\
\hline Senescent $\mathrm{T}$ cells ${ }^{a}$ & $\begin{array}{l}\text { Unknown for senescent } \mathrm{CD} 4^{+} \mathrm{T} \text { cells; unknown } \\
\text { for senescent } \mathrm{CD} 8^{+} \mathrm{T} \text { cells }\end{array}$ & $\begin{array}{l}\text { Unknown for senescent } \mathrm{CD} 4^{+} \mathrm{T} \text { cells }{ }^{a} \text {; un-known for senescent } \\
\mathrm{CD} 8^{+} \mathrm{T} \text { cells }\end{array}$ \\
\hline Innate immunity & Early slight decrease in INF- $a$ secretion ${ }^{e}$ & Early pronounced decrease in INF- $a$ secretion ${ }^{e}$ \\
\hline Vaginal physiology & Increased cervical viral shedding [12]; unknown & $\begin{array}{l}\text { Increased cervical viral shedding ([12]); increased prevalence of } \\
\text { Chlamydia infection ([10]) }\end{array}$ \\
\hline
\end{tabular}

${ }^{a}$ Markers associated with disease progression in the literature.

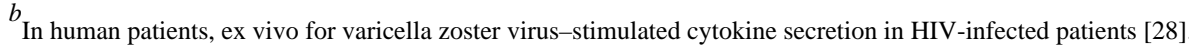

${ }^{c}$ Mouse menstrual hormone levels [29].

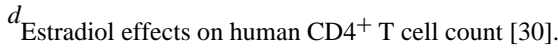

${ }^{e}$ In mouse models, significant during first $10 \mathrm{~h}$ of infection [31]. 